\title{
A walk through the park - Do people know the animals living in urban parks?
}

Bruno Ferreira Guilhon ( $\nabla$ brunoguilhon.bio@gmail.com )

Universidade Federal do Ceará https://orcid.org/0000-0001-9052-709X

João Fabrício Mota Rodrigues

Universidade Federal de Goias

Diva Maria Borges-Nojosa

Universidade Federal do Ceará

Research

Keywords: Ethnozoology, Environmental education, Protected areas, Zoology

Posted Date: May 26th, 2020

DOI: https://doi.org/10.21203/rs.3.rs-30490/v1

License: (1) This work is licensed under a Creative Commons Attribution 4.0 International License.

Read Full License 
$4 \quad$ Institutional addresses

5 Departamento de Biologia, Centro de Ciências, Universidade Federal do Ceará, Fortaleza, CE, 6 Brazil.

$7 \quad$ BFG, DMBG

8 Departamento de Ecologia, Instituto de Ciências Biológicas, Universidade Federal de Goiás, 9 Goiânia, GO, Brazil.

10 JFMR

\section{Corresponding author}

\section{Email addresses of other authors}

DMBN:dmbnojosa@yhaoo.com.br

JFMR: fabriciorodrigues303@gmail.com 


\section{Abstract}

Background: It is important that people know the fauna occurring around the city and within it, because people could present a more positive relationship toward animals and valorize the fauna. This knowledge may vary due to cultural features of the region, as well as social characteristics of the person, such as: educational level and frequency of visits to green areas. This study aimed to evaluate if the knowledge about the faunistic diversity of an urban park varied in relation to the profile of the visitors.

Methods: Parque Estadual do Cocó is a conservation unit, located in the Fortaleza municipality in Ceará state, which has a very diverse fauna. We collected the data between September and October 2018 using a structured questionnaire applied with 126 park visitors.

Results: We observed that visitors only know $31.57 \%$ of the fauna of the Parque Estadual do Cocó and usually find $1.05 \pm 1.29$ animals during the activities realized in the place. "Common marmoset" (Callithrix jacchus) and "Great egret" (Ardea alba) were the most cited species, with respectively 102 and 63 citations, while "Crab-eating raccoon" (Procyon cancrivorus) and "American purple gallinule" (Porphyrio martinicus) were the less cited, with 22 and 16 citations. We did not notice a relationship between the knowledge about the Park fauna with frequency of visitation, but we noticed a positive relation between the number of animals sighted and frequency. The most cited source of information about the Park native species was information boards, but there was no relation between the presence of boards with an animal species of the Park and the knowledge of visitor about them.

Conclusions: Visitors do not know the species richness of the Park, even with a high frequency of visitation and the presence of information boards about the Park fauna. However, a high frequency of visitation allowed people to see more animals throughout these visitations. Possibly, more direct alternatives to inform visitors about the native fauna of the Park can 
bring more positive results than just the sightings and simply the presence of information boards.

\section{Keywords: Ethnozoology, Environmental education, Protected areas, Zoology}

\section{Background}

Open green areas are very important for the quality of life in society. In urban parks, for example, is possible to find a wide variety of people of different sociodemographic conditions and with most diverse motivations to visit nature $[1,2]$. These spaces may provide important ecosystem services, aiding in the mitigation of temperature, carbon sequestering, prevention of floods from the rainwater drainage, and it acts as a refuge for wildlife [3,4]. Urban parks also provide a space for recreation and health benefits for visitors [1], being comfortable places to visit and relax, attracting many visitors for these reasons.

When we think about urban spaces it is almost intuitive to conclude that nature is not present, or the diversity of species is very low [5]. Indeed, urbanization causes several impacts and modification in nature, like fragmentation and habitat disturbance [6]. Despite this, the species still resist and occupy remaining fragments of vegetation in natural areas of the city, especially urban parks, which reinforce the importance of biodiversity conservation and researches in this natural areas surrounded by urbanization $[7,8]$.

The knowledge about animal species, beyond that achieved by science, is also related to traditional knowledge. This knowledge is commonly originated from experiences of past generations with the nature that were transmitted orally to future generations [9-11]. People, besides sharing space with fauna, recognize and name animals by following their own locally categories and names. In this way, biodiversity also belongs to the cultural domain, and 
culture enables people to understand and know the fauna $[12,13]$. Knowing the name of a specie is also an important feature that indicates the connectivity between people and nature, showing a closer interaction with these living beings [14,15].

Some cultural and social factors can affect attitudes, perceptions [16] and knowledge related to animals [17]. There may be qualitative and quantitative variations of this knowledge according to age $[2,18]$, level of schooling $[19,20]$ and, in case of animals found in green areas or natural parks, frequency of visitation [2]. According to these authors, frequency of visitation in urban parks shows a positive relation with knowledge about the local fauna. The most frequent visitors tend to know more animals than the less frequent visitors and people who do not visit the park, because occasional learning may occur, and visitors can also be able to encounter more animals during activities in the park.

Therefore, due to the importance of urban parks for the urban environment and the necessity to preserve its biodiversity, we evaluated if park visitors know the wildlife that occur within that area of the city. Thus, our study aimed to understand the knowledge of visitors of an urban park related to the native wildlife and how the profile of visitors affects their knowledge about park fauna. Then, more specifically we aimed to observe if this knowledge varies according to visitor's frequency of visitation and the presence of the animal's species in the information boards of the park. We expected that people that visit the park more frequently would be able to know more about the animals of the park and the animals represented in information boards will be more known.

\section{Methods}

\section{Study area}


We conducted this study in the Parque Estadual do Cocó, an urban park within the city of Fortaleza, Ceará, northeastern Brazil. Formerly, the area in which today is the park used to be a saltern, but it was deactivated in the 70's. After that, the area for the Park was demarcated, but it spent a lot of time without a protective status. Just recently, the "Parque Estadual do Cocó" was officially inaugurated (by state decree $n^{\circ} 32248$ of July 4, 2017) as a Conservation Unit. The Park was regularized with an area of 1571 ha, which covers the cities of Fortaleza and Maracanaú until the mouth of the Cocó river in Sabiaguaba beach [21].

The Park is characterized by a large part of Dune Fields, Coastal Plains, Coastal Tabuleiro, Caatinga and Mangrove vegetation, mainly by White, Black and Red Mangrove [22]. In this remaining of vegetation inhabit several species of amphibians (16), reptiles (24) and mammals (8) (AGUIAR et al., 2020, no prelo) and birds (162) (ARCADIS, 2020, no prelo), representing a refuge for many wildlife animals in the city. The touristic part of the Park allows visitation only between 05:30 and 17:45, its surroundings are fenced, and there are areas fragmented by roads. Inside there is a dense forest that borders the trails that cover the extension of the Park that have, in all, about $2.015 \mathrm{~km}$ length, where the visitors can pass through by bike or hiking, also with dogs. Besides, visitors often use the touristic part for picnics or other gatherings. In this area, there are 60 information boards about the flora, fauna, environment, and history of the Park. There are eight information boards focused on animals. There are also some environmental educators (EE) to explain about the biodiversity and history of the park to the visitors.

\section{Questionnaire}

We interviewed 126 visitors at the touristic part of the Park using a questionnaire (Appendix A and B). The questionnaire included closed and open-ended question, and usually 
took five minutes to complete. We applied it between September 08 and October 21, 2018.

117 Each interview started with an introduction about the study and its aims, and then we allowed

118 the visitors to answer the questions. The participation in the study was not obligatory and we

119 asked the visitors whether they explicitly consent the use of the data in the research (See 120 Appendix A and B). We did not ask for any other personal information of the visitors, as their 121 names, monthly income or their identity number. This study was part of the author's 122 monograph, and the data present in this study are a subset of those obtained in the 123 questionnaire (Table 1).

125 Table 1 - Questions addressed in the questionnaire applied in the Parque Estadual do Cocó and used in this study.

126 Possible answers of closed questions in parenthesis.

1. Age, gender (m/f), public or private school and educational level (1st to 9th grade of primary school; 1st to 3rd grade of secondary school, college, master and doctorate.)

2. How often do you visit the Parque Estadual do Cocó? (first time, irregular, once a month, every week, more than once a week)

3. What activities do you perform or participate in the Park? Have you ever seen any animal during these activities? Which are? (More than one activity and animal can be cited per visitor)

4. Which of these animals occur in the Parque Estadual do Cocó?

5. What is the source information of your knowledge about the animals of Cocó Park? (TV; Newspaper; Environmental Educators; Information boards; Internet; Friends/Family; School; Sightings or Others) 


\section{Species Selection}

To understand the species recognized by visitors as native animals of Parque Estadual do Cocó, we made a list with 18 species that occur in the park, in addition with more six exotic animals that do not belong to the Park fauna (Table 2). To help respondents to recognize the animals, the popular names were presented in the list and we showed pictures of every animal using a smartphone while the respondent was marking those they know occur in the Park.

\section{Data Analysis}

The knowledge of visitors related to park fauna was estimated as the number of native animals marked (NNAM) and the number of native animals sighted (NNAS), from the answers of the fourth and the third question, respectively, excluding the domestic and invasive species of the city fauna. To observe if NNAM and NNAS were related to frequency of visitation we performed two tests. First, we tested the assumptions of homoscedasticity and normality for all the variables, then we used an ANOVA to evaluate the relationship between NNAM (dependent variable) and the frequency of visitation (independent variable). For the NNAS we performed the same tests.

To know whether the species group (mammal, reptile or bird) influence the knowledge and citation frequency of these animals by visitors, we performed an ANOVA with the number of citations of each native species (NCENS) as the dependent variable and the group that they belong as the independent variable. To observe whether this knowledge varies with the presence of the animal species in information boards of the park (present or absent), we performed a t test between the NCENS and the presence of the species in these boards. 
We analyzed the variables using a significance level of $\mathrm{P}<0.05$. In this study, we performed all the analysis using $\mathrm{R}$ version 3.5.1 (Development Core Team, 2018).

157 Results

158 We observed that the profile of the visitors of Parque Estadual do Cocó corresponds to people 159 between 13 and 83 years (mean \pm standard deviation; $33.04 \pm 15.18$ years), almost the same proportion of male and female (Table 3). Most visitors completed the secondary school, visit the Park at a low frequency (first time or irregular) and carry out activities involving physical exercises at the Park area.

Insert Table 3

They saw few animals during the activities in the Park $(1.05 \pm 1.29$ NNAS $)$ and knew few animals $(5.683 \pm 4.76$ NNAM). Most visitors cited (Binomial name and number of citations in parentheses) Common marmoset (C. jacchus, 102) and Great egret (A. alba, 63), while Crab-eating raccoon (P. cancrivorus, 22) and American purple gallinule (P. martinicus, 16) were the less known (Figure 1). Some visitors also claimed to exist in the Park some species that do not belong to Park fauna: Black-striped capuchin (S. libidinosus, 27), Araripe manakin (A. bokermanni, 19), Bushmaster (L. muta, 12), Eastern gray squirrel (S. carolinensis, 173 11), Bald eagle (H. leucocephalus, 8) and Reticulated python (M. reticulatus, 10). Although mammals were the most cited group of animals, cited by $35 \%$ of visitors, while reptiles and 
175 birds by $32 \%$ and $28 \%$, respectively, this difference was not significant $(\mathrm{F}=0.779, \mathrm{df}=2,15$, $176 \mathrm{p}=0.254)$ (Figure 2).

177 The two sources of knowledge about the animals most cited by visitors were 178 information boards (64) and sightings (58), but few visitors cited the EE (9) (Figure 3). Eight 179 animals of the 18 native species of the questionnaire were presented in the information boards. 180 We did not find any influence of the information boards of the park on NCENS $(\mathrm{t}=-1.288$, df $181=9.0281, \mathrm{p}=0.2298)($ Figure 4$)$.

Insert Figure 1.

Insert Figure 2.

Insert Figure 3.

Insert Figure 4.

The NNAM was not influenced by frequency of visitation $(\mathrm{F}=1.127, \mathrm{df}=4.121, \mathrm{p}=$ 


\section{Discussion}

The visitors of the Parque Estadual do Cocó, during their activities, saw more animals with the increase of their frequency of visitation. It was expected, since gradually new encounters with species and even incidental learning may occur with each new visit [2]. . However, despite that, they still saw few species, just seeing $5.83 \%$ of the species listed on questionnaire and $0.54 \%$ of all Park native species. Most visitors cite "sightings" as their source of information about Park fauna. Although encounters with animals are relatively frequent in the touristic part of the Park, some species are rare to be seen and others occupy areas that general public usually do not visit. The great length of the park makes it impossible, in fact, for visitors to see various species of local fauna. In this way, sightings cannot be a very informative source about the park's species richness.

Frequency of visitation is not related with NNAM, and most visitors also know few species of the park native fauna, with the NNAM average being $31.57 \%$ of the total number of animals listed and only $2.92 \%$ of all Park species. This may be associated with the use of the Park space for purposes, mostly, involving physical activities and leisure. In this way, observe or learn about animals are not the primary purpose and focus of visitors' attention. This scenario could be observed in others urban and national parks [23-25]. Then, Park space could work just as a pleasant background for these purposes, making undervalued the environmental attractions and species richness that the park has to offer. These low values of NNAM and NNAS seen to indicate that visitors are still not well informed about the composition of the Park native animals.

Despite most visitors have marked information boards as one of their main sources of information about the Park fauna, the animal species that were represented on these boards were not mentioned more frequently than those that were not represented. These boards are a 
reliable source of information about these species, and Park management made them in order to inform visitors. But maybe the information boards were not being so effective in informing visitors about the native fauna, even more because the species present on these boards still represent only a small portion of the Park native species. Thus, in order to properly inform visitors about the native fauna, in addition to the information on the boards and visual contact with the fauna, it may be necessary to interact with people who actually know the species that inhabit the Park and who can pass on these information with more attention [26], in this case, the environmental educators of the Park.

Therefore, we noticed that just the existence of information boards and visitors encountering fauna do not guarantee that they will be able to know the wildlife species of the Park, because the native fauna of the Park is more than visitors could see on visits and observe on these boards. They still need to be accompanied and informed by environmental educators or others who know about the Park native species.

In this way, encouraging visitors to participate in environmental activities may be an alternative for them to learn and care more about the environment [27]. For that purpose, the environmental educators should work with the visitors for provide to them more information about the nature of the Park to, in this way, change their behavior and increase their 237 knowledge [28]. This can help to make the Park's environmental beauty and fauna more attractive and interesting to visitors, thus enabling greater contact, appreciation and even the recognition of the conservation importance of them. Such recognition could be a reinforcement for the conservation of this protected area, by the improvement of conservation attitudes of visitors [29], since public support is very important to assist in the success of conservation projects and management [30]. 


\section{Conclusions}

245 Our study shows that frequency of visitation is not related to the number of species known by 246 visitors, but rather to the number of species that visitors see in the studied park. However, 247 despite having this positive relation between the number of native animals sighted with 248 frequency of visitation, this number is still considerably low in comparison to the number of 249 animal species covered in the research and, principally, the whole richness of native species 250 of the Park. In addition, information boards do not seem to be effective in informing visitors 251 about the native fauna. In this way, other direct alternatives of information transmission could 252 be more efficient. More investments in environmental education and activities that provide an 253 active community involvement would be an interesting alternative because visitors may be 254 more likely to learn and valorize the fauna.

256 Abbreviations

257 EE: environmental educators

258 NNAM: Number of Native Animals Marked

259 NAAS: Number of Native Animals Sighted

260 NCENS: Number of Citations of Each Native Species

262 Declarations

263 Ethics approval and consent to participate

264 Before conducting interviews, oral and written consent, explicit by marking the authorization 265 question, was received from visitors regarding data collection and publication. No further 266 ethics approval was required. We followed the ethical guidelines of the International Society 

268 data of the interviewers.

270 Consent for publication

271 Not applicable.

\section{Availability of data and materials}

274 The datasets used during the current study are available from the corresponding author on 275 reasonable request.

\section{Competing interests}

278 The authors declare that they have no competing interests.

\section{Funding}

281 This research did not receive funding for its realization.

\section{Authors' contributions}

BFG conceived the main idea of the manuscript. BFG, JFMR, DMBN delineated the study. 285 BFG collected and analysed the data. BFG and JFMR interpreted the results. BFG wrote the 286 first draft of the manuscript. BFG, JFMR and DMBN provided substantial contributions to the final version of the manuscript. All authors read and approved the final manuscript. 


\section{Acknowledgments}

290 We would like to acknowledge everyone who assisted during the data collection. We would 291 like to thank the Dr. Hugo Fernandes-Ferreira and Dr. Vicente Vieira Faria for providing 292 interesting suggestions in a previous version of the paper; to the Parque Estadual do Cocó 293 management and to the master Cecilia Licarião Barreto Luna to the partnership and 294 collaboration during the research in the Park area; to the master Raul Rodrigues Vasconcelos 295 for providing statistical support and suggestions in the initial phase of the project. JFMR was 296 supported by an INCT DTI researcher fellowship (grant \#380759/2017-9) and by a 297 CNPq/PDJ fellowship (grant \#154177/2018-0).

299 Authors' information

300 Departamento de Biologia, Centro de Ciências, Universidade Federal do Ceará, Fortaleza, CE, 301 Brazil.

302 BFG, DMBG

303 Departamento de Ecologia, Instituto de Ciências Biológicas, Universidade Federal de Goiás, 304 Goiânia, GO, Brazil.

305 JFMR 


\section{REFERENCES}

312 1. Chiesura A. The role of urban parks for the sustainable city. Landsc Urban Plan. $3132004 ; 68: 129-38$.

2. Randler C, Höllwarth A, Schaal S, Randler C. Urban park visitors and their knowledge of 315 animal species. Anthrozoos. 2007;20:65-74.

3. Constanza R, D’Arge R, Groot R, Farber S, Grasso M, Hannon B, Limburg K, Naeem S, O'Neil RV, Paruelo J, Raskin RG, Sutton P, Belt MVD. The value of the world's ecosystem services and natural capital. Nature. 1997;387:253-60.

4. Bolund P, Hunhammar S. Ecosystem services in urban areas Per. Ecol Econ. 1999;29:293301.

5. Sukopp H, Werner P. Urban environments and vegetation. Man's impact Veg. Boston: Dr W. Junk Publishers; 1983. p. 247-60.

6. Atchison KA, Rodewald AD. The Value of Urban Forests to Wintering Birds. Nat Areas J. 2006;26:280-8.

7. Farinha-Marques P, Lameiras JM, Fernandes C, Silva S. Urban biodiversity: a review of current concepts and contributions to multidisciplinary approaches. Innov Eur J Soc Sci Res. $2011 ; 24: 247-71$.

8. Nielsen AB, van den Bosch M, Maruthaveeran S, van den Bosch CK. Species richness in urban parks and its drivers: A review of empirical evidence. Urban Ecosyst. 2014;17:305-27. Applied Anthropology in Amazonian Development. Hum Organ. 1984;43:95-107. 
Ethnobiol. 2005;25:93-114.

11. Santos-fita D, Costa-Neto E. As interações entre os seres humanos e os animais : a contribuição da etnozoologia Resumo Introdução. Biotemas. 2007;20:99-110.

12. Berkes F, Colding J, Folke C. Rediscovery of Traditional Ecological Knowledge as Adaptive Management. Ecol Appl. 2000;10:1251-62.

13. Diegues AC, Arruda RSV, da Silva VCF, Figols FAB, Andrade D. Saber tradicional, ciência e biodiversidade. Biodiversidade e Comunidades Tradic no Bras. São Paulo: NUPAUB-USP/PROBIO-MMA/CNPq; 2000. p. 30-4.

14. Campos CM, Greco S, Ciarlante JJ, Balangione M, Bender JB, Nates J, LindemannMatthies P. Students' familiarity and initial contact with species in the Monte desert (Mendoza, Argentina). J Arid Environ. Elsevier Ltd; 2012;82:98-105.

15. de Oliveira JV, de Faria Lopes S, Barboza RRD, de Melo Brito Trovão DM, Ramos MB, Nóbrega Alves RR. Wild vertebrates and their representation by urban/rural students in a region of northeast Brazil. $\mathrm{J}$ Ethnobiol Ethnomed. Journal of Ethnobiology and Ethnomedicine; 2019;15:1-23.

16. Serpell JA. Factors influencing human attitudes to animals and their welfare. Anim Welf. 2004;13:S145-151.

17. Ellen RF. Indigenous Knowledge of the Rainforest. Hum Act Trop Rainfor. Springer, Dordrecht; 1998. p. 87-99.

18. Kellert SR. Attitudes toward animals: Age-related development among. J Environ Educ. 1985;16:29-39.

19. Kellert SR, Berry JK. Knowledge, Affection and Basic Attitudes Toward Animals in American Society. Phase III. Washington, DC: U.S. Dept. of the Interior, Fish and Wildlife 
Service; 1980.

357 358 359 360

20. Pinheiro LT, Rodrigues JFM, Borges-Nojosa DM. Formal education, previous interaction and perception influence the attitudes of people toward the conservation of snakes in a large urban center of northeastern Brazil. J Ethnobiol Ethnomed. Journal of Ethnobiology and Ethnomedicine; 2016;12:25.

21. PREFEITURA DE FORTALEZA. Arquivos KMLs e KMZs [Internet]. Canal Urban. e Meio Ambient. 2019 [accessed 2019 Apr 28]. Available from: https://urbanismoemeioambiente.fortaleza.ce.gov.br/infocidade/11-arquivos-kml-s-e-kmz-s.

22. Moro MF, Macedo MB, De Moura-Fè MM, Farias Castro AS, Da Costa RC. Vegetação, unidades fitoecológicas e diversidade paisagística do estado do Ceará. Rodriguesia. 2015;66:717-43.

23. Malta RR, da Costa NMC. Gestão do Uso Público em Unidade de Conservação : a Visitação no Parque Nacional da Tijuca - RJ. Rev Bras Ecoturismo. 2009;2:273-94.

24. Viana ÁL, Lopes MC, Lins Neto NFDA, Kudo SA, Guimarães DFDS, Mari MLG. Análise Da Percepção Ambiental Sobre Os Parques Urbanos Da Cidade De Manaus, Amazonas. Rev Monogr Ambient. 2014;13:4044-62.

25. Mello GF de, Ribeiro AÍ, Bongiovanni S. Percepção dos usuários do Parque Ecológico "João Domingos Coelho", Assis (SP), quanto ao meio ambiente e aves, antes e após a implantação de placas informativas da avifauna local. Rev Bras Educ Ambient. 2015;10:17799.

26. Pegoraro JL, Sorrentino M. Programas educativos com flora e fauna (expressões da biodiversidade) e a educação ambiental Educational. Sci For. 1998;131-42.

27. Haron SA, Paim L, Yahaya N. Towards sustainable consumption: an examination of 

environmental knowledge among Malaysians. Int J Consum Stud. 2005;29:426-36.

380 28. Pooley JA, O’Connor M. Environmental Education and Attitudes: Emotions and Beliefs 381 are What is Needed. Environ Behav. 2000;32:711-23.

382 29. Randler C, Wagner A, Rögele A, Hummel E, Tomažic I. Attitudes toward and Knowledge 383 about Wolves in SW German Secondary School Pupils from within and outside an Area 384 Occupied by Wolves (Canis lupus). Animals. 2020;10:1-10.

385 30. Bremner A, Park K. Public attitudes to the management of invasive non-native species in 386 Scotland. Biol Conserv. 2007;139:306-14. 
400

Figures

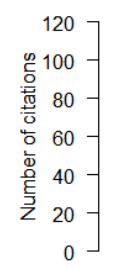

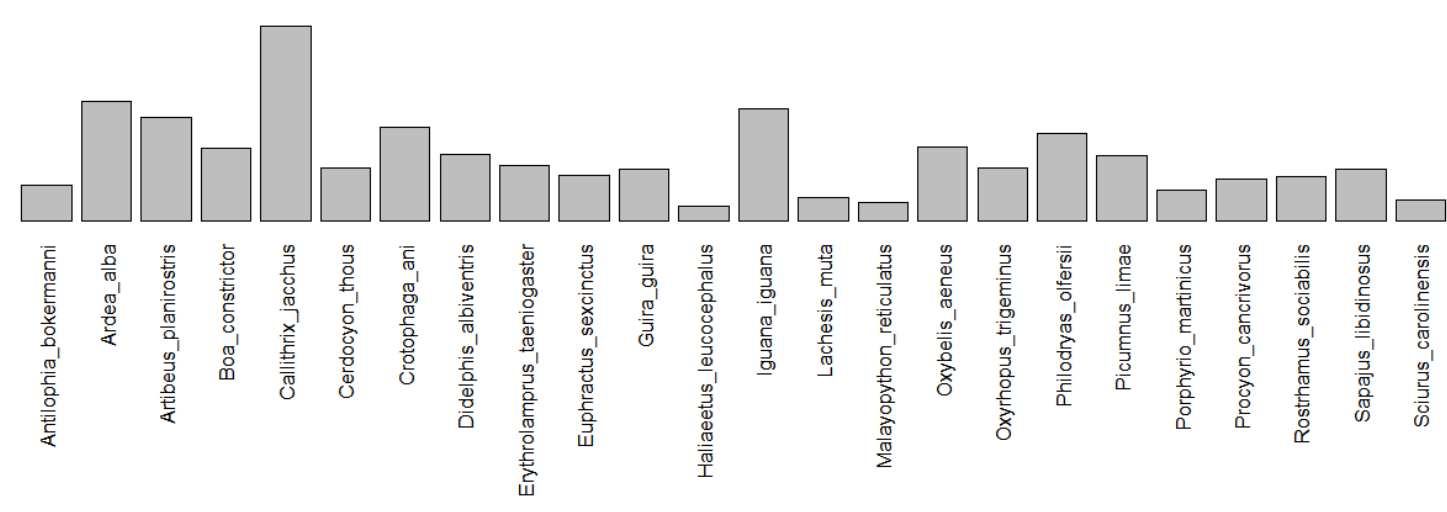

401

402 Figure 1. Frequency of citation of each animal species cited by visitors of Parque Estadual do

403 Cocó, Fortaleza, Ceará, Brazil.

404

405

406

407

408

409

410

411 


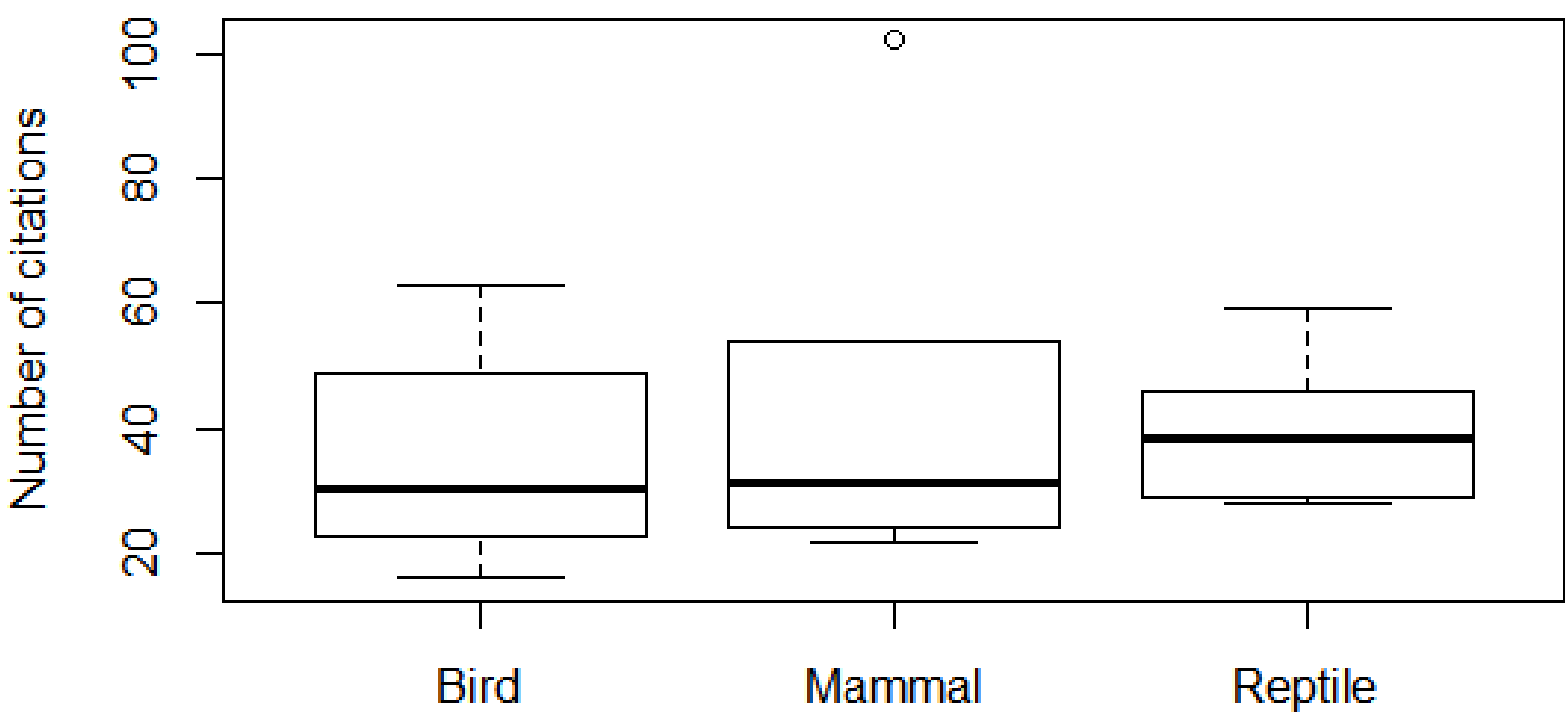

413 Figure 2. Relation between Number of Citations of Each Native Species (NCENS) and the 414 vertebrate group that they belong.

415

416

417

418

419

420

421

422

423 
424

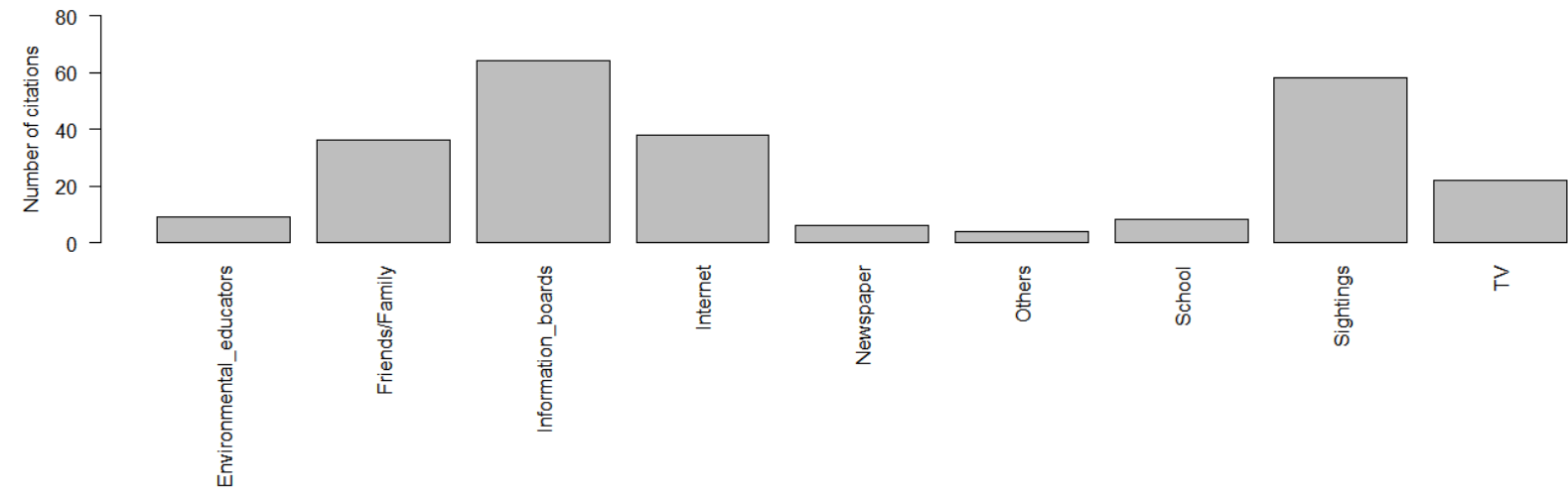

425 Figure 3. Frequency of citation of each information source category about the Parque Estadual

426 do Cocó fauna marked by visitors.

427

428

429

430

431

432

433

434 


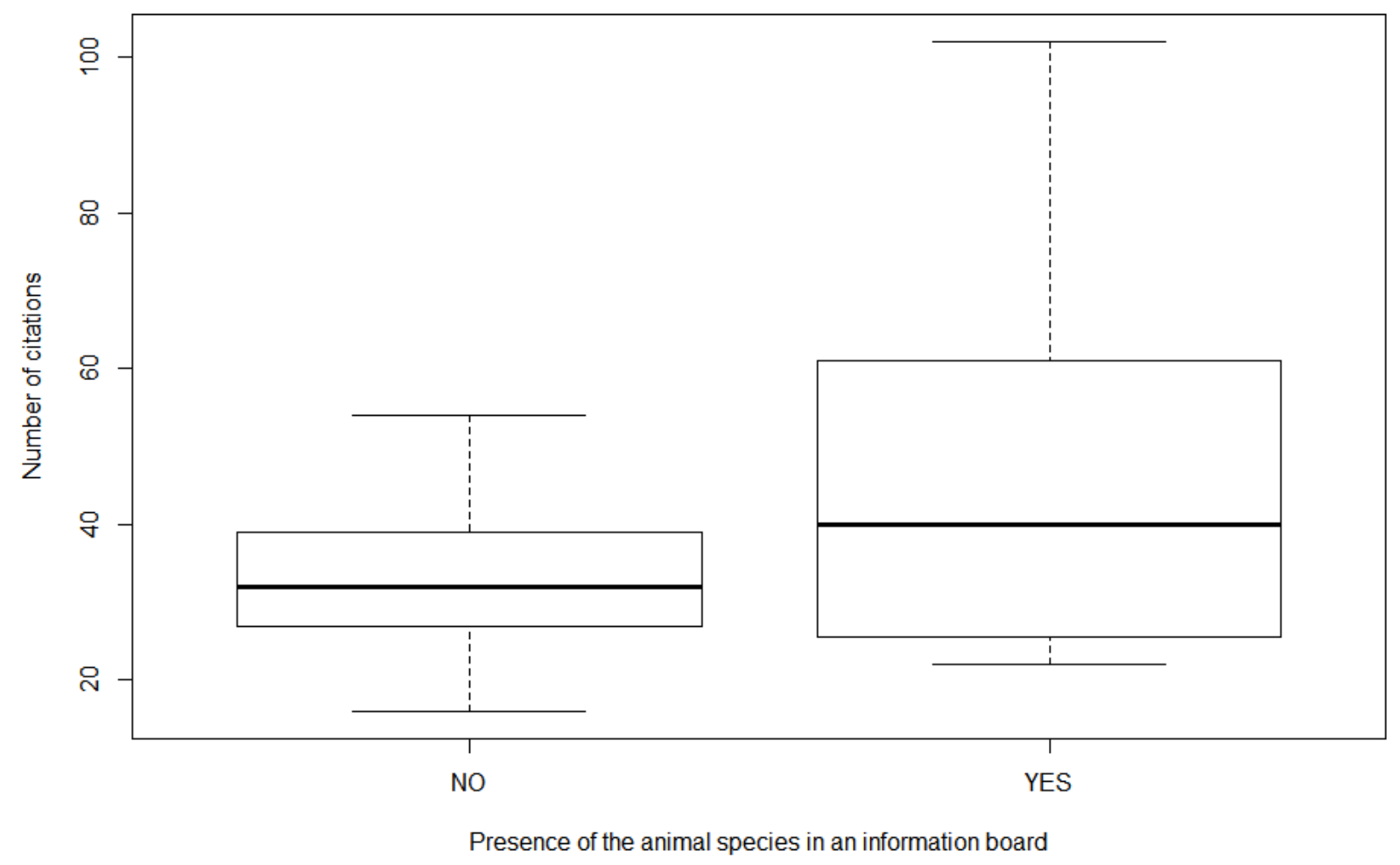

436 Figure 4. Relation between Number of Citation of Each Native Species (NCENS) and the 437 presence of an information board about it at the Parque Estadual do Cocó, Fortaleza, Ceará, 438 Brazil. 


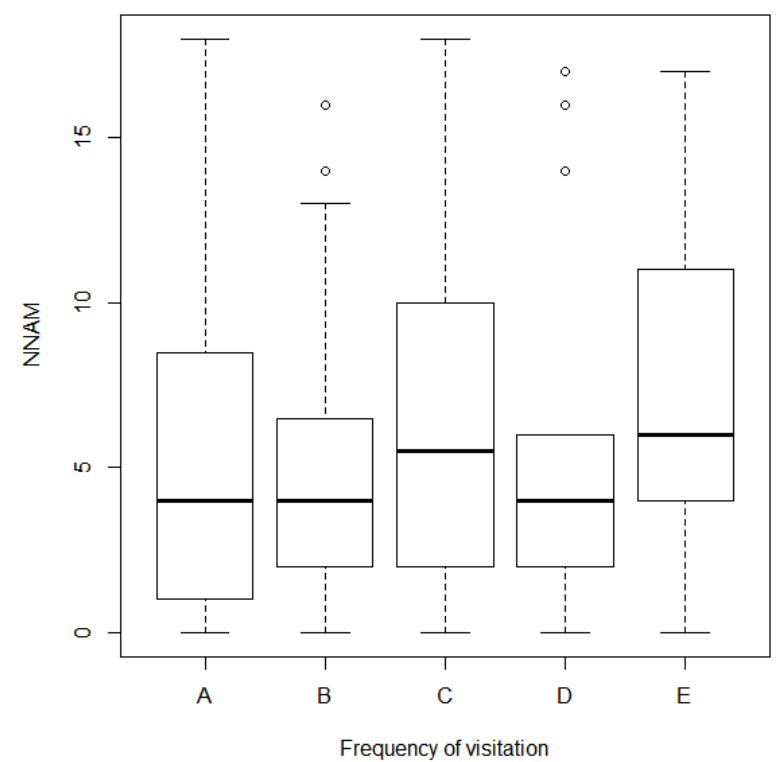

b)

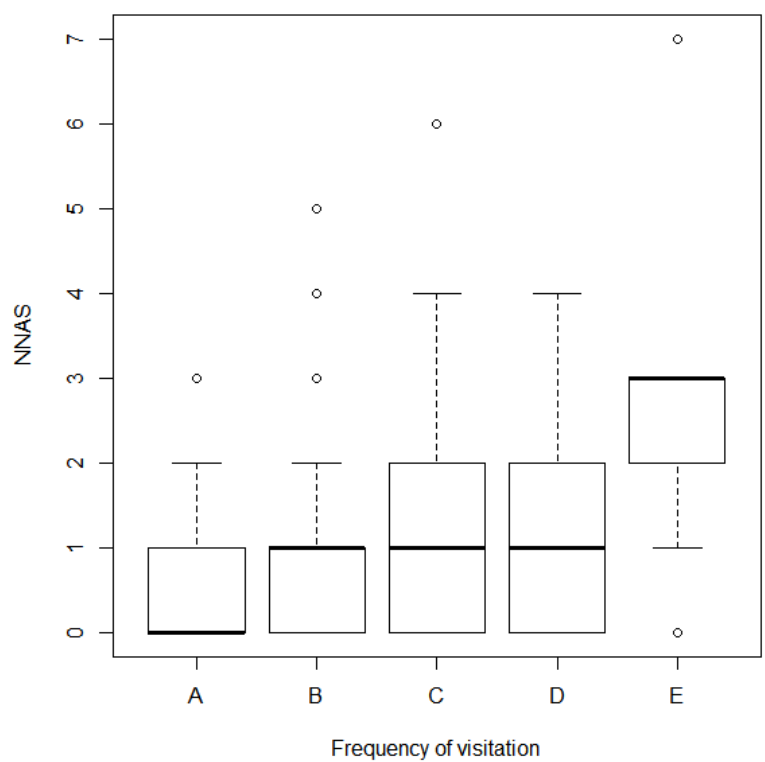

449 Figure 5. Relation between frequency of visitation at the Parque Estadual do Cocó with: a)

450 Number of Native Animals Marked (NNAM), b) Number of Native Animals Sighted (NNAS).

$451 \mathrm{~A}=$ First time; $\mathrm{B}=$ Irregular; $\mathrm{C}=$ Once a month; $\mathrm{D}=$ Once a week $\mathrm{E}=$ More than once a 452 week. 
463 Table 2- List of species selected, presented in the interviews in the Parque Estadual do Cocó,

464 Fortaleza, Ceará, Brazil.

\begin{tabular}{|c|c|c|c|}
\hline Popular name & Binomial name & Status & Information boards \\
\hline Six-banded armadillo & Euphractus sexcinctus & Native & Absent \\
\hline Black-striped capuchin & Sapajus libidinosus & Does not occur & Absent \\
\hline Crab-eating fox & Cerdocyon thous & Native & Present \\
\hline White-eared opossum & Didelphis albiventris & Native & Absent \\
\hline Flat-faced fruit-eating & Artibeus planirostris & Native & Absent \\
\hline \multicolumn{4}{|l|}{ bat } \\
\hline Common marmoset & Callithrix jacchus & Native & Present \\
\hline Crab-eating raccoon & Procyon cancrivorus & Native & Present \\
\hline Eastern gray squirrel & Sciurus carolinensis & Does not occur & Absent \\
\hline Great egret & Ardea alba & Native & Present \\
\hline Snail kite & Rostrhamus sociabilis & Native & Present \\
\hline Guira cuckoo & Guira guira & Native & Absent \\
\hline Smooth-billed ani & Crotophaga ani & Native & Absent \\
\hline Bald eagle & Haliaeetus leucocephalus & Does not occur & Absent \\
\hline Purple gallinule & Porphyrio martinicus & Native & Absent \\
\hline Araripe manakin & Antilophia bokermanni & Does not occur & Absent \\
\hline Ochraceous piculet & Picumnus limae & Native & Present \\
\hline Green iguana & Iguana iguana & Native & Present \\
\hline Common boa & Boa constrictor & Native & Absent \\
\hline Reticulated python & Malayopython reticulatus & Does not occur & Absent \\
\hline
\end{tabular}




$\begin{array}{llll}\text { Bush master } & \text { Lachesis muta } & \text { Does not occur } & \text { Absent } \\ \text { South american } & \text { Erythrolamprus taeniogaster } & \text { Native } & \text { Absent } \\ \text { swampsnakes } & & & \\ \text { Brown vine snake } & \text { Oxybelis aeneus } & \text { Native } & \text { Absent } \\ \text { False coral snake } & \text { Oxyrhopus trigeminus } & \text { Native } & \text { Absent } \\ \text { South American green } & \text { Philodryas olfersii } & \text { Native } & \text { Present } \\ \text { racer } & & & \end{array}$

465

466

467

468

469

470

471

472

473

474

475

476 
477 Table 3- Profile of the visitors of the Parque Estadual do Cocó, Fortaleza, Ceará, Brazil $(\mathrm{n}=$ 478 126).

\begin{tabular}{|c|c|c|}
\hline Variable & Information & Number of visitors \\
\hline \multirow[t]{8}{*}{ Age (years) } & $<20$ & 20 \\
\hline & $20>29$ & 46 \\
\hline & $30>39$ & 19 \\
\hline & $40>49$ & 17 \\
\hline & $50>59$ & 17 \\
\hline & $60>69$ & 4 \\
\hline & $70>79$ & 2 \\
\hline & $>80$ & 1 \\
\hline \multirow[t]{2}{*}{ Gender } & Male & 62 \\
\hline & Female & 64 \\
\hline \multirow[t]{5}{*}{ Level of schooling } & Primary incomplete & 5 \\
\hline & Primary complete & 5 \\
\hline & Secondary incomplete & 7 \\
\hline & Secondary complete & 73 \\
\hline & College complete & 36 \\
\hline \multirow[t]{5}{*}{ Frequency } & First time & 39 \\
\hline & Irregular & 39 \\
\hline & Once a month & 26 \\
\hline & Every week & 13 \\
\hline & More than once a week & 9 \\
\hline \multirow[t]{2}{*}{ Activities } & Trails & 40 \\
\hline & Hiking & 64 \\
\hline
\end{tabular}




\begin{tabular}{cc}
\hline Picnic & 34 \\
Cycling & 6 \\
Photography & 5 \\
Weight training & 4 \\
Observe fauna & 3 \\
Others & 16 \\
\hline
\end{tabular}

479

480

481

482

483

484

485

486

487

488

489

490

491 
495 Você está sendo convidado para participar da pesquisa Conhecendo a Fauna do Cocó, do 496 aluno Bruno Ferreira Guilhon, do curso de Ciências Biológicas da Universidade Federal do 497 Ceará. Nós nos comprometemos a utilizar os dados coletados apenas para a referente pesquisa, 498 e os questionários individuais serão compartilhados apenas entres os pesquisadores 499 envolvidos.

500 [ ] Autorizo a utilização dos dados para a pesquisa.

1. Idade:

Sexo: [ ] Masculino [ ] Feminino

Escolaridade - Escola: [ ] Pública [ ] Privada

2. Você visita o Parque do Cocó com que frequência?

[ ] Não vou com frequência

[ ] Uma vez por mês

[ ] Toda semana

[ ] Mais de uma vez por semana 
3. Que atividades você realiza ou participa no Parque do Cocó? Você já viu algum animal durante essas atividades?

\begin{tabular}{|l|l|l|}
\hline Atividade & Sim/Não & Nome do Animal \\
\hline & & \\
\hline & & \\
\hline & & \\
\hline & & \\
\hline
\end{tabular}

4. Quais desses animais ocorrem no Parque do Cocó?

[ ] Tatu

[ ] Garça

[ ] Iguana/Camaleão

[ ] Macaco Prego

[ ] Gavião Caramujeiro

[ ] Jiboia

[ ] Raposa

[ ] Anu Branco

[ ] Píton

[ ] Cassaco

[ ] Anu Preto

[ ] Surucucu

[ ] Morcego

[ ] Águia

[ ] Cobra D’água

[ ] Soim/Sagui

[ ] Frango D’água Azul

[ ] Cobra Cipó

[ ] Mão-pelada/Guaxinim

[ ] Soldadinho do Araripe

[ ] Falsa Coral

[ ] Esquilo

[ ] Pica Pau

[ ] Cobra Verde

5. Qual a fonte dos seus conhecimentos sobre os animais do Parque do Cocó?

[ ] TV [ ] Jornal [ ] Educadores Ambientais do Parque [ ] Placas do Parque [ ] Internet [ ] Amigos/Família [ ] Escola

[ ] Avistamento no Parque [ ] Outro:

6. Você acha que os gatos abandonados que vivem no parque podem ter algum impacto aos animais silvestres do parque? Por quê? 
555 You are being invited to participate in the study "Knowing the Fauna of Cocó" by the student 556 Bruno Ferreira Guilhon, from the Biological Sciences course at the Universidade Federal do 557 Ceará. We are committed to use the data collected only for the respective research, and the 558 individual questionnaires will be shared only between the researchers involved.

559 [ ] I authorize the use of the data for research.

\section{QUESTIONNAIRE KNOWING THE FAUNA OF COCÓ}

1. Age:

Gender: [ ] Masculino [ ] Feminino

Schooling - School: [ ] Public [ ] Private

Elementary school: [ ]1st [ ]2nd [ ]3rd [ ]4th [ ]5th [ ]6th [ ]7th

[ ]8th

[ ]9th

High school: [ ]1st [ ]2nd [ ]3rd

University education: [ ] Undergraduate [ ] Master [ ] Doctorate

2. How often do you visit the Park?

[ ] First time

[ ] Irregular

[ ] Once a month

[ ] Every week

[ ] More than once a week

3. What activities do you realize or participate on Cocó Park? Have you ever seen any animal during these activities? 


\begin{tabular}{|l|l|l|}
\hline Activity & Yes/No & Name of the Animal \\
\hline & & \\
\hline & & \\
\hline & & \\
\hline & & \\
\hline
\end{tabular}

577 4. Which of these animals occur on Cocó Park?

[ ] Six-banded armadillo [ ] Great egret

[ ] Green iguana

[ ] Black-striped capuchin [ ] Snail kite

[ ] Common boa

[ ] Crab-eating fox

[ ] Guira cuckoo

[ ]Reticulated python

[ ] White-eared opossum

[ ] Smooth-billed ani

[ ] Bush master

[ ] Flat-faced fruit-eating bat[ ] Bald eagle

[ ]South American swampsnake

[ ] Common marmoset [ ] Purple gallinule

[ ] Brown vine snake

[ ] Crab-eating raccon

[ ] Araripe manakin

[ ] False coral snake

[ ] Eastern gray squirrel

[ ] Ochraceous piculet

[ ] South American green racer

5. What is the source information of your knowledge about the animals of Cocó Park?

[ ] TV [ ] Newspaper [ ] Enviromental educators of Park

[ ] Information boards of Park [ ] Internet [ ] Friend/Family

[ ] School [ ] Sightings on Park[ ] Other:

6. Do you think that abandoned cats that live in the park can have an impact on the park's wild animals? Why? 
Figures
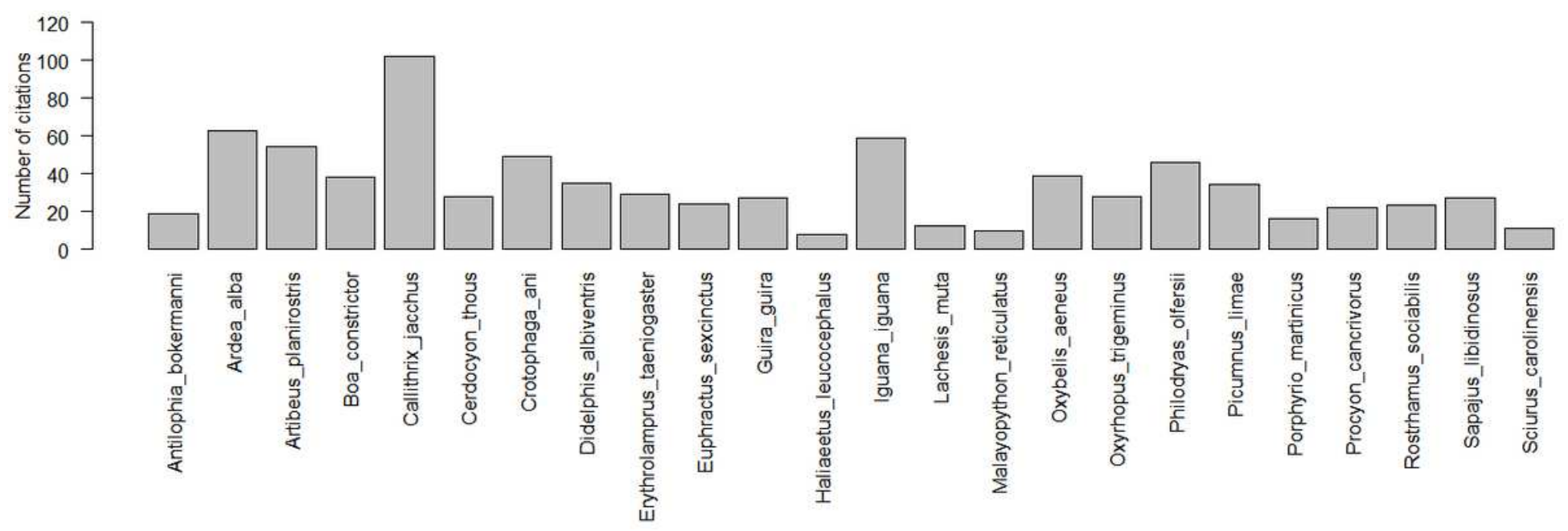

Figure 1

Frequency of citation of each animal species cited by visitors of Parque Estadual do Cocó, Fortaleza, Ceará, Brazil.

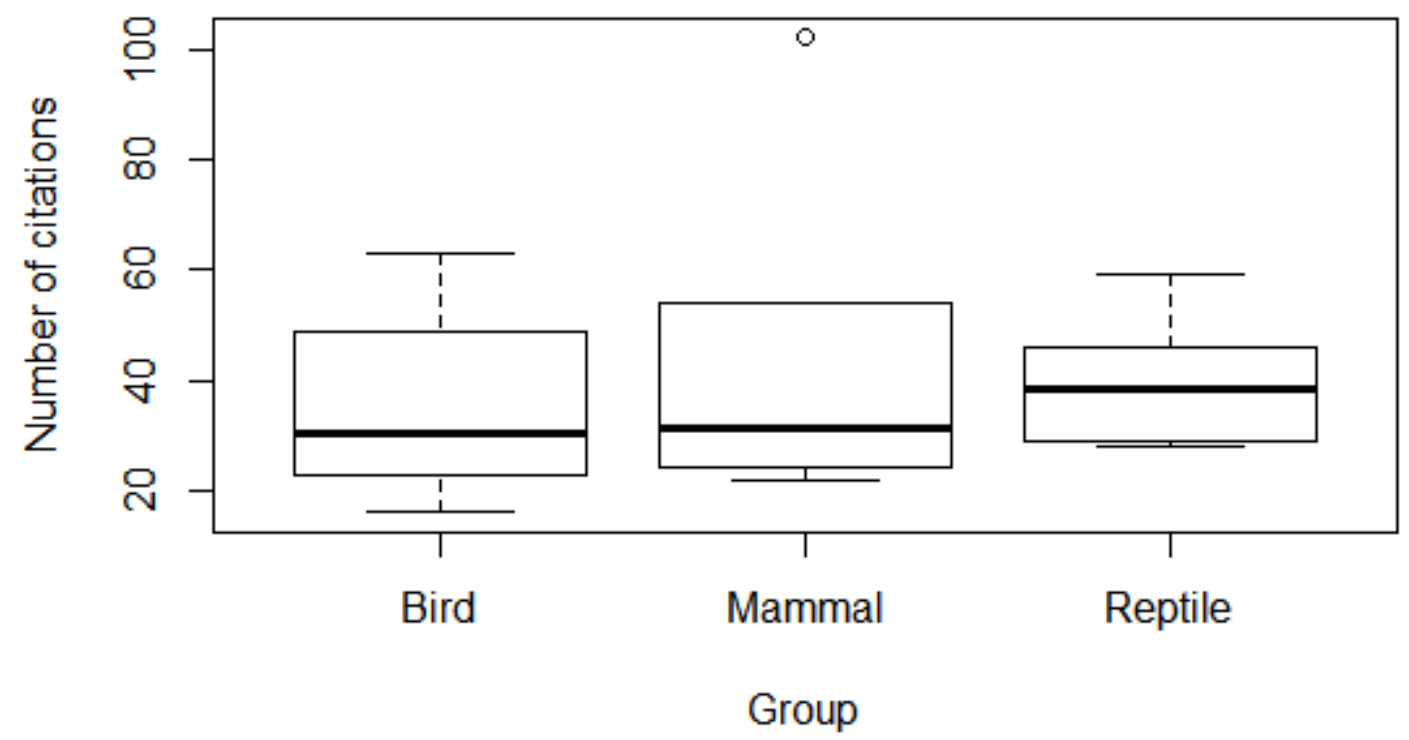

Figure 2

Relation between Number of Citations of Each Native Species (NCENS) and the vertebrate group that they belong. 


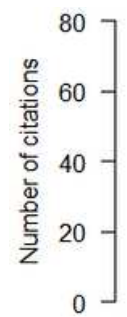

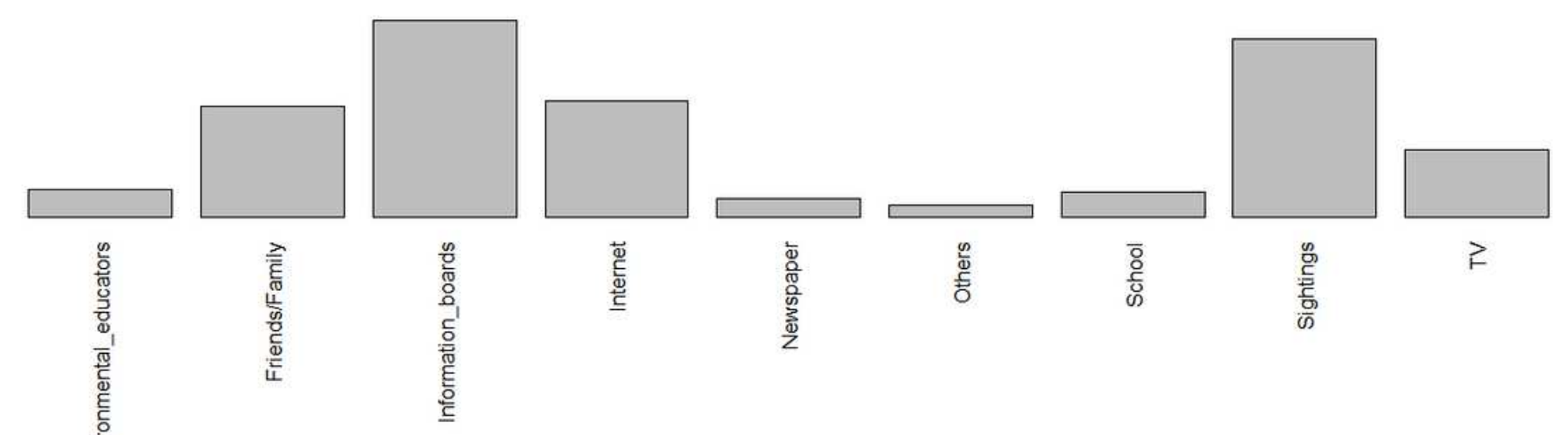

\section{Figure 3}

Frequency of citation of each information source category about the Parque Estadual do Cocó fauna marked by visitors.

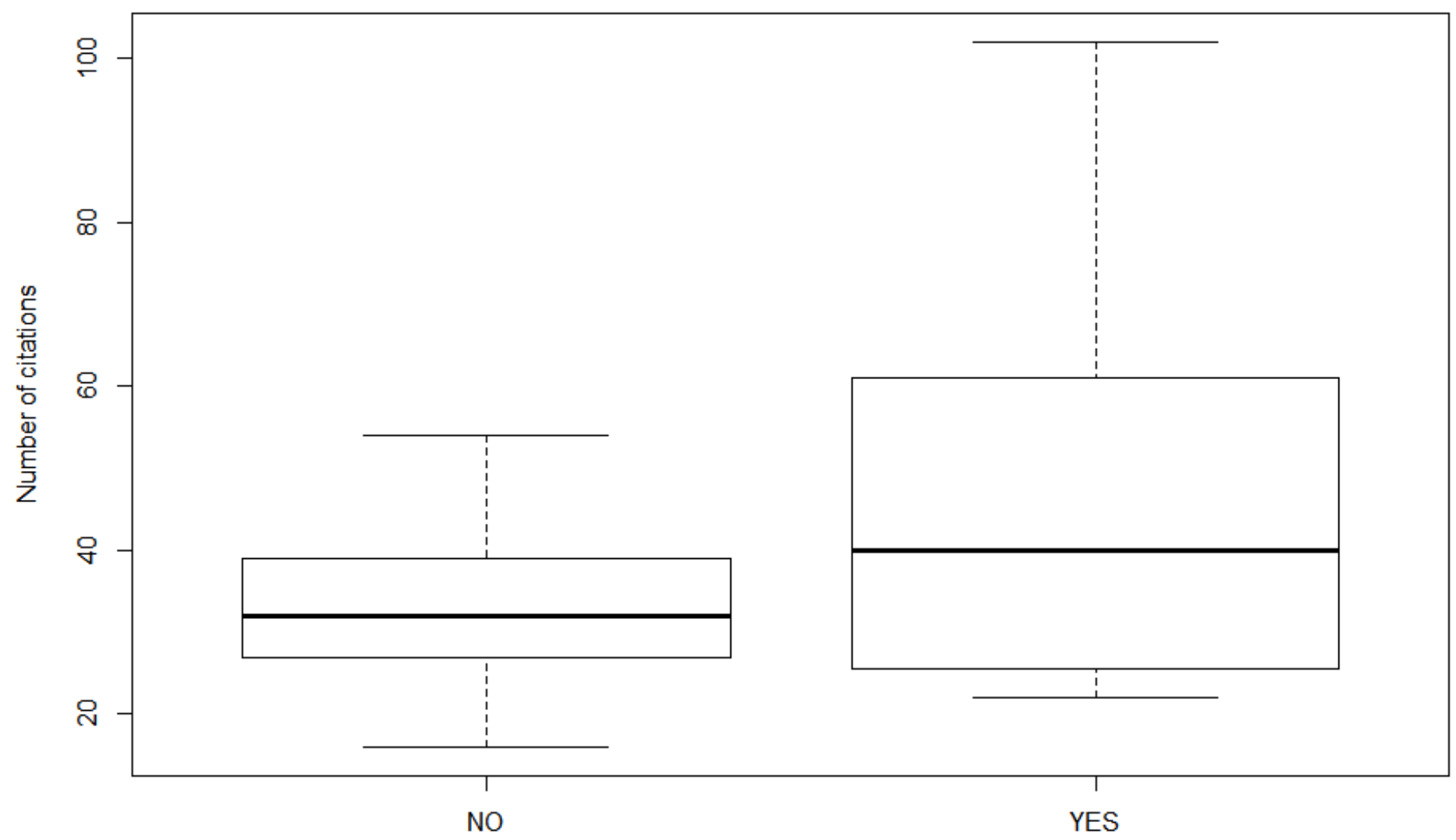

Presence of the animal species in an information board

Figure 4 
Relation between Number of Citation of Each Native Species (NCENS) and the presence of an information board about it at the Parque Estadual do Cocó, Fortaleza, Ceará, Brazil.

a)

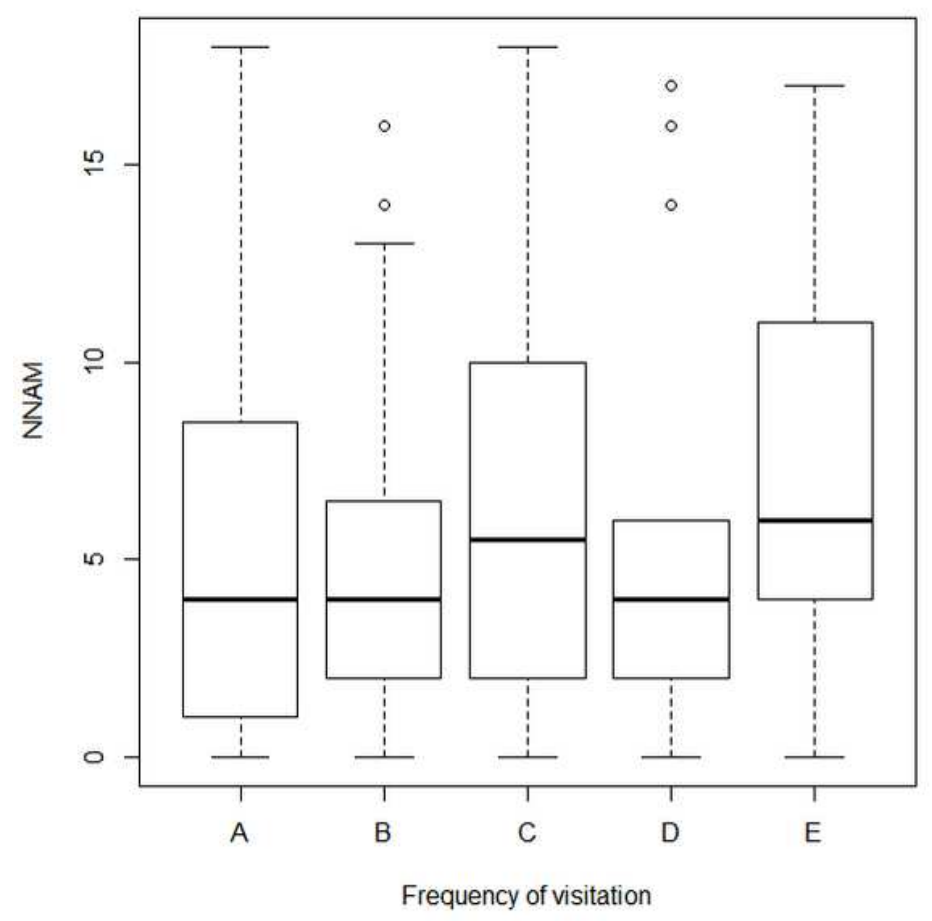

b)

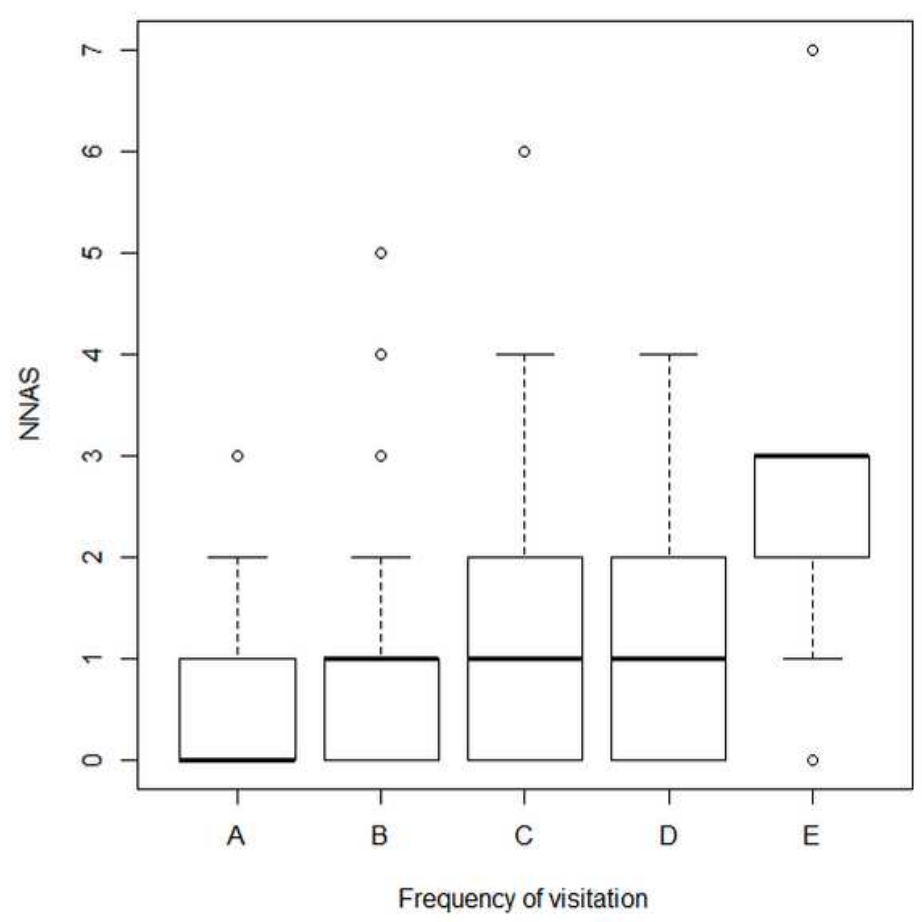

Figure 5

Relation between frequency of visitation at the Parque Estadual do Cocó with: a) Number of Native Animals Marked (NNAM), b) Number of Native Animals Sighted (NNAS). $A=$ First time; $B=$ Irregular; $\mathrm{C}=$ Once a month; $\mathrm{D}=$ Once a week; $\mathrm{E}=$ More than once a week.

\section{Supplementary Files}

This is a list of supplementary files associated with this preprint. Click to download.

- AppendixB.pdf

- AppendixA.pdf 